\title{
JAN SCHELLER \\ Braterstwo sakramentalne w relacjach proboszcz - wikariusz w kontekście posoborowych Synodów Archidiecezji Poznańskiej
}

Zagadnienie braterstwa sakramentalnego między kapłanami jest sprawą niezwykle ważną dla obecnych problemów Kościoła. Już nauka Soboru Watykańskiego II wypowiadała się na ten temat, widząc konieczność budowania we współczesnym świecie prawdziwych więzi przyjaźni między kapłanami na różnych jej poziomach. Problem braterstwa w relacji proboszcz - wikariusz został również poruszony w dokumentach soborowych, choć jak wiadomo, ponieważ dotyczy on szczegółowych odniesień na szczeblu Kościoła diecezjalnego - w życiu parafialnym kapłanów między soba, został opracowany stosunkowo zwięźle, pozostawiając szczegółowe zalecenia Kodeksowi Prawa Kanonicznego ${ }^{1}$ oraz synodom w poszczególnych diecezjach.

Problematykę kapłaństwa i wynikające z niego relacje Sobór Watykański II podjął w kilku dokumentach. Składają się na nie niektóre rozdziały Konstytucji dogmatycznej o Kościele Lumen gentium, Dekret o pasterskich zadaniach biskupów w Kościele Christus Dominus, Dekret o formacji kapłanów Optatam totius, Dekret o posłudze i życiu kapłanów Presbyterorum ordinis ${ }^{2}$. W oparciu o wymienione dokumenty, przy uwzględnieniu konkretnych sytuacji, rozważaniami na temat kapłaństwa zajęly się Synody Poznańskie w latach 1968 i 1992-93 formułując odpowiednie statuty i dekrety.

\footnotetext{
${ }^{1}$ Kodeks Prawa Kanonicznego. Poznań 1984.

${ }^{2}$ Dokumenty cyt. za: Sobór Watykański II. Konstytucje. Dekrety. Deklaracje. Poznań 1986.
} 


\section{Pouczenia Synodów Poznańskich}

Problemy poruszane i omawiane w Dokumentach Soboru Watykańskiego II, po zakończeniu obrad Soboru miały zostać przez Kościół wprowadzane w życie. Kościół Poznański, jako jeden z pierwszych w Polsce, dzięki usilnym staraniom ówczesnego arcybiskupa metropolity Antoniego Baraniaka, podją zadanie analizy dokumentów soborowych i dla realizacji tych zadań ogłosił w 1968 r. Synod Archidiecezjalny. Wiele spraw poruszanych w dokumentach soborowych było na nowo dyskutowanych i dostosowywanych do warunków naszej diecezji. Efektem prac Synodu było ogłoszenie Statutów Archidiecezjalnego Synodu Poznańskiego, w których punktem wyjścia stały się dokumenty Soboru Watykańskiego II, a następnie ich przeniesienia na grunt Archidiecezji Poznańskiej.

Synod podją przede wszystkim problemy dotyczące duszpasterstwa oraz sprecyzował szczegółowe zalecenia dotyczące kapłaństwa, w tym kapłaństwa hierarchicznego, a także interesujący nas w niniejszej pracy stosunek relacji proboszcz - wikariusz. W Statutach wymienione zostały wskazania dotyczące zadań i obowiązków proboszczów oraz wikariuszy. Podkreślono zwłaszcza konieczność gorliwości pasterskiej kapłanów oraz postawy służebnej na wzór Chrystusa.

Proboszcz - główny duszpasterz parafii, jako współpracownik biskupa, według zaleceń synodalnych ma traktować swoje zadania jako najszczytniejszq służbę i poświęcać im wszystkie swoje siły fizyczne i umysłowe ${ }^{3}$. Jako pasterz, proboszcz powinien starać się o to, by wszystkie czynności liturgiczne sprawowane były z należytą czcią i godnością; winien dbać o rozwój życia religijnego parafian, należyte nauczanie i głoszenie Słowa Bożego, katechizację. Jego zadaniem jest stałe poszukiwanie nowych form duszpasterskich, bardziej skutecznych i dostosowanych do zmieniających się warunków życia. Proboszcz powinien jak najlepiej poznać parafian i współuczestniczyć z nimi we wszystkich sprawach codziennego życia oraz traktować wszystkich z jednakową miłością, a zwłaszcza mieć na względzie troskę o błądzących i grzeszacych, polecając ich w swoich modlitwach milosiernemu Bogu ${ }^{4}$.

Na tle zadań proboszcza wobec parafii i parafian szczególnie ważny jest jego stosunek do swego współpracownika, jakim jest wikariusz. Zgodnie z zaleceniami Soboru Watykańskiego II między proboszczem a wikariuszem winno mieć miejsce bratnie wspótżycie i kwitnq̨ć wzajemna mitość oraz poważanie ${ }^{5}$. Synod rozwija naukę soborowa, dając konkretne wskazówki na ten temat: duch wspól-

\footnotetext{
${ }^{3}$ Statuty Archidiecezjalnego Synody Poznańskiego 1968. Poznań 1972 , 1004 (dalej: SASP)

${ }^{4}$ Por. SASP $1006-1017$.

${ }^{5}$ DB 30,3.
} 
noty $i$ charakter pracy zespołowej wymagajq od proboszcza, by dzielqc sie ze swoimi wspólpracownikami odpowiedzialnościq za dobro Ludu Bożego, uzgadniał z nimi wytyczne pracy duszpasterskiej oraz chętnie wysłuchiwal ich opinii i sugesti1 ${ }^{6}$.

Proboszcz jako starszy wiekiem i doświadczeniem (...) musi być dla swoich współpracowników przykładem kapłańskiej gorliwości i systematycznej pracy. Jeśli potrzeba, taktownie i z życzliwościq korygować błędy i niedociqgnięciā. Zadaniem proboszcza jest troska o rozwój własnego życia wewnętrznego i umysłowego, ale również zabieganie o postęp duchowy i intelektualny swoich mlodszych współpracowników ${ }^{8}$.

Zainteresowanie proboszcza powinno odejmować również sprawy bytowe wikariusza. Powinien on, kierując się poczuciem ogólnoludzkiej sprawiedliwości i w duchu ewangelicznej wspólnoty zapewnić wikariuszowi odpowiednie warunki materialne, takie jak: mieszkanie, wynagrodzenie, wyżywienie, jak również wykazywać troskę o jego zdrowie ${ }^{9}$. Proboszcz winien dążyć do realizacji życia wspólnotowego. Ta wspólnota kaplańska winna być najbardziej widoczna w codziennym życiu kapłanów na probostwie. Synod zobowiązal proboszczów do dążeń w kierunku budowy tej wspólnoty. Stąd, oprócz wymienionych wyżej przejawów tych relacji, proboszcz powinien zadbać o wspólnotę stołu z wikariuszami nawet $w$ wypadku zamieszkania ich poza plebaniq ${ }^{10}$.

Statuty Synodu przywołujac osobę wikariusza, przypominaja co na ten temat orzekł Sobór Watykański II w Dekrecie o pasterskich zadaniach biskupów w Kościele: wikariusze są współpracownikami proboszcza; między nimi a proboszczem powinna wytworzyć się bratnia $i$ wzajemna miłość oraz poważanie, powinni wzajemnie służyć sobie radq, pomocq i przykładem, roztaczajqc opiekę nad parafiq w zgodności dq̨żeń i zespoleniu wysitków ${ }^{11}$.

Wikariusz winien uznać stanowisko, wiek i doświadczenie przełożonego oraz chętnie poddawać się jego kierownictwu. Stąd winien ochotnie $i$ sumiennie wypełniać zlecenia proboszcza w zakresie pracy duszpasterskiej, administracyjnej i kancelaryjnej; z należytq czciq odnosić się do proboszcza, przyjmować jego

\footnotetext{
${ }^{6}$ SASP 1020.

${ }^{7}$ Tamże, 1021

${ }^{8}$ Por. tamże, 1022

${ }^{9}$ Por. tamże, 1023.

${ }^{10}$ Tamże, 1024.

${ }^{11}$ Por. DB 30,3 oraz SASP 1045.
} 
upomnienia oraz gorliwie wspierać go w trudach podejmowanych dla sprawy $B o \dot{z} e j^{12}$.

Dla wikariusza, zwlaszcza młodego neoprezbitera, przykład proboszcza odgrywa ogromną rolę w kształtowaniu własnej wizji kapłaństwa u progu zadań jakich się podjąl w dniu święceń. Dlatego w proboszczu wikariusz powinien spotkać starszego brata w kapłaństwie, który go życzliwie przyjmie, uzna w nim jego dobra wole $i$ chętnie wprowadzi w trudne zagadnienia pracy duszpasterskiej, a także służyć mu będzie przykładem kapłańskiego życia, gorliwości $w$ pracy, radq i doś wiadczeniem ${ }^{13}$. Wikariusz, chcąc sumiennie podjąc i realizować swoje obowiązki winien przede wszystkim starać się swoje życie wypelniać modlitwą i duchem służby Bożej; poprzez rozmyślanie, modlitwę prywatna, nawiedzanie Najświętszego Sakramentu powinien pogłębiać swoją bezpośrednią łączność z Panem Bogiem ${ }^{14}$.

Dla dobra podejmowanych działań duszpasterskich konieczna jest również współpraca między wikariuszami tej samej parafii. Winni oni między sobą rozdzielać zadania w dziedzinie pracy duszpasterskiej, a niektóre obowiązki parafialne spełniać według kolejności ustalonej przez proboszcza. Zawsze powinni służyć sobie ofiarną pomocą i chętnym zastapieniem w razie potrzeby ${ }^{15}$. W gestii proboszcza jest wyznaczenie wikariuszowi jednego dnia w tygodniu wolnego od zajęć duszpasterskich. Dzień wolny przysługuje z racji intensywnej pracy parafialnej w niedzielę, a ma służyć wikariuszowi odnowieniu sil przez wypoczynek, modlitwę i studium ${ }^{16}$.

Statuty synodalne poświęcaja kilka punktów sprawom podziału funkcji między proboszczem a wikariuszem w parafii. Na przykład: wikariusz otrzymuje od ordynariusza generalną delegację do asystowaniu przy zawieraniu związków małżeńskich na terenie parafii, jednak do godziwego z niej korzystania wymagana jest zgoda proboszcza. Statuty wymieniają szereg czynności, które proboszcz i wikariusz mogą wypełniać na zmianę, należą do nich: celebracja mszy św., odprawianie nabożeństw, głoszenie kazań, dyżury w biurze parafialnym, zaopatrywanie chorych, odprawianie pogrzebów, o ile dekret nominacyjny nie stanowi inaczej lub gdy proboszcz nie zarządzi czego innego ${ }^{17}$.

\footnotetext{
${ }^{12}$ SASP 1046.

${ }^{13}$ Tamże, 1047.

${ }^{14}$ Por. tamże, 1050.

${ }^{15}$ Por. tamże, 1048.

${ }^{16}$ Por. tamże, 1049.

${ }^{17}$ Por. tamże, $1057-1058$.
} 
Ponadto Statuty szczególowo odnoszą się do spraw utrzymania wikariusza, jego poborów, mieszkania, leczenia, opieki w razie choroby, dojazdów służbowych, wlasnego gospodarstwa, stypendiów mszalnych, wpływów okazyjnych, ofiar kolędowych ${ }^{18}$.

Statuty Synodu z 1968 r. odnoszą się również do obowiązku współpracy prezbiterów z parafią odnośnie katechezy. Zgodnie ze statutem 1066, gdzie jest mowa o dużych parafiach, powstał problem ustanowienia osobnego wikariusza, zwanego katechetą młodzieży, który poświęcałby się sprawom katechezy. Kaplani - wikariusze katecheci powinni uzgodnić z proboszczem plan lekcji religii (był to okres, kiedy lekcje religii odbywać się mogły wylącznie przy parafiach), powinni również ustalić plan pracy wychowawczej, organizacji nabożeństw i rekolekcji dla młodzieży. Taki wikariusz powinien ponadto pomagać $w$ miarę możliwości w duszpasterstwie parafialnym, zwłaszcza $w$ głoszeniu kazań i słuchaniu spowiedzi $s w^{19}$. Proboszcz, który odpowiada za całość życia parafialnego winien utrzymywać kontakt z młodzieża, odwiedzać katechetę na lekcjach religii, odprawiać niekiedy nabożeństwa dla mlodzieży i brać udział w uroczystościach rozpoczęcia i zakończenia roku szkolnego ${ }^{20}$.

Po dwudziestu latach zwołano drugi Synod Archidiecezji Poznańskiej., w celu ponownego zgłębienia nauki soborowej oraz wniesienia w nową rzeczywistość aktualnych problemów i przedyskutowania ich, Odbywał się on pod przewodnictwem metropolity poznańskiego abp. Jerzego Stroby. Po czterech latach przygotowań w grupach synodalnych na terenie całej archidiecezji, w latach 1992—93 odbyly się właściwe dyskusje i sformułowano odpowiednie dekrety.

W sprawach dotyczacych współdziałania kapłanów Synod przypomniał naukę o służebnym charakterze kapłaństwa i na tym tle określił przyczyny i formy współdziałania kaplanów między sobą, kapłanów z wiernymi, a przede wszystkim ze swoim biskupem ${ }^{21}$.

Synod za Soborem Watykańskim II przypomniał konieczność służebnej postawy kapłańskiej na wzór Chrystusa, jako najgłębszego motywu podejmowania dzialań duszpasterskich (por. DK 12), istotę i zadania wspólnoty hierarchicznej, posłuszeństwo jako wyraz pasterskiej miłości oraz praktykowanie ducha ubóstwa (por. DK 17) ${ }^{22}$.

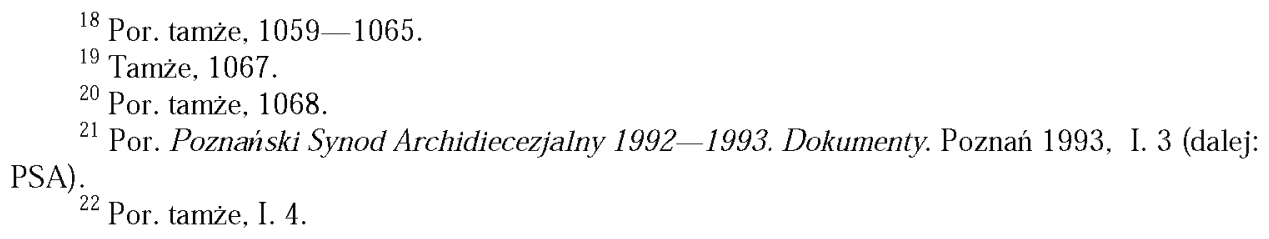

${ }^{21}$ Por. Poznański Synod Archidiecezjalny 1992-1993. Dokumenty. Poznań 1993, I. 3 (dalej:

${ }^{22}$ Por. tamże, I. 4. 
Przypomniano także stanowisko Synodu Archidiecezjalnego z 1968 r. dotyczace potrzeby rozwijania wspólnoty kapłańskiej wyrastającej $\mathrm{z}$ harmonijnego współdziałania: doskonała wspólnota diecezjalna, polegajaca na ścisłej jedności duchowej kapłanów i wiernych z biskupem, stanowi podporę świętości każdego sługi Chrystusowego (statut 1116) ${ }^{23}$.

Synod z 1992-93 r. kontynuując naukę poprzedniego Synodu pragnąl bliżej określić ramy i formy faktycznego wspóldziałania kapłanów z biskupem, ze współbraćmi - kapłanami, a także z wiernymi ${ }^{24}$. Według nauki Synodu służebny charakter kapłaństwa ujawnia się na co dzień w zdyscyplinowaniu wyrażajqccym się $w$ podejmowaniu i realizowaniu zadań jemu powierzonych $h^{25}$. Kaplan powierzone mu zadania powinien wypełniać w perspektywie celów określonych przez Kościól, a nie przez pryzmat własnych interesów i według wlasnego uznania. Winien rozwijać w sobie postawę zaangażowania, polegającą na utożsamianiu własnych dążeń z pragnieniami Chrystusa Arcykapłana oraz pogłębiać świadomość odpowiedzialności za wykonanie zleconych mu przez Kościól zadań. Każdy kapłan swoim życiem i pracą powinien dawać świadectwo swego oddania Chrystusowi. Stąd jego postawę musi charakteryzować głęboka kultura osobista, wyrażająca się m.in. troską o estetyczny, skromny, zależny od okoliczności strój i kulturalny sposób bycia w kontaktach z ludźmi. Kapłan powinien rozwijać w sobie odpowiedzialność za Kościól Powszechny, archidiecezjalny, a przede wszystkim tę jego cząstkę, do której został posłany, a w nim za swoich braci kapłanów ${ }^{26}$.

Synod wymienia płaszczyzny wspóldziałania kapłanów. Są nimi relacje: $\mathrm{z}$ biskupem, między sobą i z wiernymi. Wszyscy kapłani pracujqcy w Archidiecezji Poznańskiej, tak diecezjalni, jak i zakonni, pozostajq w jedności z Arcybiskupem Poznańskim jako »pilni współpracownicy« (KK 28) w dziele ewangelizacji, tworzq wspólnote archidiecezjalnego prezbiterium ${ }^{27}$. Omawiając relacje międzykapłańskie Synod zwrócił szczególną uwage na współdziałanie proboszcza z wikariuszami danymi mu do pomocy. Dokumenty synodalne przypominają, że Kodeks Prawa Kanonicznego jasno ustala prawa i obowiązki proboszcza. Zagadnienia to zostało szczególowo omówione w statutach (1004-1944) Synodu Archidiecezji Poznańskiej z 1968 r. Ponadto Synod podkreśla, że normy prawne

\footnotetext{
${ }^{23}$ Por. tamże, I.5.

${ }^{24}$ Por. tamże, I.6.

${ }^{25}$ Tamże.

${ }^{26}$ Por. tamże, I.6.

27 Tamże, I.1.
} 
obowiązujące na terenie naszej Archidiecezji publikowane są w „Miesięczniku Kościelnym Archidiecezji Poznańskiej"28.

Dokumenty Synodu z lat 1992-93 omawiają najpierw zadania proboszcza, są nimi: organizowanie wzajemnej współpracy i takie nią kierowanie, by przynosiła dobre owoce, planowanie pracy duszpasterskiej w swojej parafii wraz z wikariuszami, podział pracy i organizacja dyżurów parafialnych, troska o dalsza formację wikariuszy. W centrum tej formacji winny się znaleźć następujące zagadnienia: sposób sprawowania mszy św., szafarstwo sakramentów, życie modlitwy, ale także kultura bycia - strój, zachowanie się w towarzystwie, kragg znajomych, stosunek do kobiet, sposób wykorzystania dnia wolnego i wakacji. Dokumenty podkreślaja, że niezwykle ważna jest postawa samego proboszcza - życzliwa i otwarta, choć nie poblażliwa, atmosfera zaufania i chęć dialogu z wikariuszem, polegającego na wysłuchaniu jego racji i przedstawieniu mu swoich argumentów. Stworzeniu takiego klimatu sprzyja, jak zauważa Synod, wspólne mieszkanie proboszcza i wikariuszy, wspólne posiłki, a przede wszystkim własna kapłańska postawa spełniająca zasadniczą rolę $e^{29}$.

W odniesieniu do wikariuszy Synod przypomina naukę Soboru Watykańskiego II zawartą szczególnie w Dekrecie o pasterskich zadaniach biskupów w Kościele (DB 30,3). Podkreślając współodpowiedzialność wikariuszy za parafię jednoznacznie stwierdza konieczność poddania się woli i poleceniom proboszcza, który jest inspiratorem i koordynatorem całej pracy duszpasterskiej, i który musi zdać sprawę ze swoich przedsięwzięć przed biskupem, ale przede wszystkim ostatecznie przed Bogiem. Dlatego wikariusz winien wspomagać wysilki proboszcza, nigdy nie działać wbrew jego wiedzy lub przeciw wyraźnie przez niego określonym planom, czy sformułowanym zadaniom ${ }^{30}$. Wikariusze $\mathrm{w}$ pracę duszpasterską powinni wkładać wszystkie swoje uzdolnienia i doświadczenia pastoralne, świeżość swojego spojrzenia, młodzieńczy entuzjazm i zaangażowanie. Wówczas ich posluga jako prezbiterów będzie odbierana jako autentyczne poświęcenie się służbie Bożej. Księża wikariusze muszą również zabiegać, aby spełniane przez nich czynności liturgiczne byly sprawowane starannie i zgodnie z ustalonymi przepisami. Ponadto winni oni sumiennie podejmować codzienne obowiązki kapłańskie - liturgię godzin, rozmyślanie, modlitwę różańcową. W kontaktach z wiernymi wikariusze powinni unikać niezdrowej poufałości oraz pamiętać o kulturze języka. W stosunkach z proboszczem, księża wikariusze powinni kierować się zasadami dobrego wychowania, a więc punktualnie zasiadać do stołu lub powiadamiać o możliwości spóźnienia, nie wracać późno do

\footnotetext{
${ }^{28}$ Por. tamże, I.12.

${ }^{29}$ Por. tamże, I.12.

${ }^{30}$ Tamże, I.13.
} 
domu, informować proboszcza o swoich gościach, a ich noclegi uzgadniać z proboszczem $^{31}$.

Podsumowując powyższe rozważania należy stwierdzić, że relacje, jakie zachodzą między proboszczem a jego wikariuszem jako współpracownikiem, mają istotny wpływ na prawidłowe funkcjonowanie całej wspólnoty parafialnej. Zasadniczym powolaniem kapłana jest przecież służba Ludowi Bożemu. Realizacja tego zadania musi dokonywać się na wielu płaszczyznach. Od właściwego podejścia kaplanów pracujących w parafii do podejmowanych obowiązków oraz ich relacji względem siebie, w ogromnej mierze zależy obfitość owoców duszpasterskich. Zarówno proboszcz, jak i wikariusze powinni swoją pracę w parafii traktować jako pierwszorzędne zadanie swego kapłańskiego powołania, $z$ ludu wzięci, dla ludzi sq ustanawiani (por. Hbr 5,1 ), a wszystko co czynią winni czynić na chwałę Bożą. Dla realizacji powierzonych prezbiterom zadań nieobojętne są więc stosunki, jakie zachodzą między proboszczem a wikariuszem. Ich wspótpraca powinna być przeniknięta duchem prawdziwego braterstwa, miłości i poważania oraz odpowiedzialnością za duszpasterstwo, czyli za budowanie Królestwa Bożego.

\section{Braterstwo sakramentalne jako najgłębsze uzasadnienie wspólnoty życia i pracy kapłanów}

Posługa kapłanów zjednoczonych najpierw z Chrystusem Najwyższym i Wiecznym Kapłanem, Głową i Pasterzem, powinna znajdować swe oparcie również w innych kaplanach, polączonych ze sobą braterstwem wynikającym z przyjętych święceń. Komunia, jaka powstaje między kapłanami powinna zmierzać do relacji, które byłyby źródłem wzajemnej miłości braterskiej i stanowiłyby wzajemne odniesienie w życiu codziennym kapłana.

\section{Przejawy braterstwa sakramentalnego $w$ relacjach między kapłanami}

Ustanowienie kapłaństwa hierarchicznego dokonało się w obrębie wspólnoty. Jezus wybrał grono Dwunastu Apostołów, następnie wysyłał ich oraz innych siedemdziesięciu dwóch uczniów do pracy misyjnej po dwóch (por. Łk 10, 1; Mk 6, 7). Czynił tak, aby zarówno udzielali sobie wzajemnej pomocy w życiu $i$ pracy, jak też i po to, aby powstał zwyczaj wspólnego działania i by nikt nie działał tak, jakby był sam, niezależnie od wspólnoty - Kościoła oraz wspólnoty Apostołów ${ }^{32}$.

\footnotetext{
31 Por. tamże

${ }^{32}$ Jan Paweł II: Posługa prezbiterów i diakonów. Poznań 1998 s. 83.
} 
Kaplani, z racji przyjętych święceń, zobowiązani są do urzeczywistniania komunii między sobą oraz ze swoim biskupem ${ }^{33}$. Wspólnota kapłanów zakłada i pociaga za sobą przylgnięcie wszystkich biskupów i prezbiterów do osoby Jezusa Chrystusa. Podczas Ostatniej Wieczerzy Jezus modlił się o jedność tych, których później rozesłal po świecie. Podstawą komunii między prezbiterami jest zatem ich więź z Chrystusem. Szczególnym wyrazem tej jedności bylo ustanowienie sakramentu Eucharystii i powierzenie jej sprawowania Apostołom.

Kapłani dzięki przyjętym święceniom, stają się reprezentantami Chrystusa. To reprezentowanie Najwyższego Kapłana, wymaga związania we wspólnotę. Każdy kapłan należąc do prezbiterium diecezjalnego, tworzy z nim jedność. Jedność ta powinna się wyrażać przede wszystkim w posłuszeństwie biskupowi diecezji, ale również w całej pracy duszpasterskiej kapłana wszędzie tam, gdzie zostaje on posłany przez władze kościelne. Praca kapłana będzie przynosiła owoce tylko wówczas, gdy będzie spełniana w duchu służby Ludowi Bożemu w łączności z innymi kapłanami. Duch braterstwa powinien przenikać wszystkich współpracujących ze sobą kapłanów na poszczególnych szczeblach ich działalności - w diecezji, dekanacie i parafii. Urzędowe posłanie, jakie ukazuje Nowy Testament $\mathrm{i}$ jakie rozwinęło się $w$ historii Kościoła, ma zasadniczo charakter wspólnotowy, ma coś z kolegialności. Jezus powoływał swoich uczniów z konkretnych rodzin, a więc ze starych więzów ludzkich, i równocześnie instalowat ich w nową rodzinę Jego braci i sióstr ${ }^{34}$. Duch Święty dany Apostolom w Dniu Pięćdziesiątnicy stal się gwarantem ich jedności. Święty Paweł w podstawowym tekście na temat urzędu (2 Kor 5) używa pierwszej osoby liczby mnogiej: my apostołowie, my - posłańcy w imię Chrystusa ${ }^{35}$. Stąd zasadniczy sens struktury kolegialnej urzędu leży w tym, aby reprezentowane przez przedstawicieli pojedyncze gminy, czy diecezje połaczyć w całość, w communio. Ale kolegialność oznacza także, iż poszczególny kapłan staje naprzeciw swojej gminy jako ten, który zwiqzany jest z braterskq wspólnotq urzę dowo powołanych uczniów Chrystusa $i$ w ten sposób zwraca uwage na Pana i Mistrza wszelkiego „uczniostwa” oraz źródło i cel braterstwa ${ }^{36}$.

Omawiając braterstwo sakramentalne jako najgłębsze uzasadnienie wspólnoty życia i pracy kaplanów zajmiemy się przejawami tego braterstwa w relacjach między kapłanami realizowane podczas spotkań dekanalnych, rekolekcji kapłańskich i w innych wspólnotach kapłańskich. 1992,74 .

${ }^{33}$ Por. KK 28 oraz Jan Paweł II: Adhortacja apostolska Pastores dabo vobis. Watykan

${ }^{34}$ Por. G. Greshake: Być kapłanem. Tłum. K. Wój towicz CR. Wroclaw 1983 s. 197.

${ }^{35}$ Por. tamże.

${ }^{36}$ Tamże. 


\section{a) Spotkania dekanalne}

Statuty Archidiecezjalnego Synodu Poznańskiego z 1968 r., podkreślając konieczność troski o rozwój braterskiej więzi między kapłanami w odniesieniu do wspólnoty dekanalnej, zobowiązują dziekana do organizowania regularnych spotkań wszystkich kapłanów dekanatu ${ }^{37}$. Dziekan jest bezpośrednim duszpasterzem kapłanów swojego dekanatu. Ma więc obowiqzek otaczania ich życzliwościq, służenia im radq i opiekq $w$ troskach duchowych i materialnych oraz oddziaływania własnym przykładem i dobrym słowem ${ }^{38}$.

Obowiazkowymi dekanalnymi dniami takich spotkań są konferencje i dni skupienia. Każdego roku powinny odbyć się przynajmniej cztery konferencje, w tym trzy zwykłe i jedna uroczysta, zwana kongregacją ${ }^{39}$. Ponadto raz w miesiącu powinien mieć miejsce dzień skupienia. Konferencje zwykłe w swym programie obejmują część ascetyczną, kongregacje - dodatkowo jeszcze bardzo rozbudowaną część liturgiczną z udziałem wiernych. Poza tym każda konferencja połaczona jest $\mathrm{z}$ referatem naukowym dotyczącym aktualnych zagadnień Kościola ${ }^{40}$. Zadaniem dziekana jest stała troska, by współżycie między kapłanami w poszczególnych parafiach rozwijało się w duchu braterskiej wspólnoty. Dlatego dziekan jako duszpasterz swego dekanatu powinien dołożyć wszelkich starań, aby kaplani pielęgnowali gościnność i darzyli się wzajemnie życzliwością i zaufaniem, stając się przez to pociagającym przykładem życia Chrystusowego dla swoich parafian (por. 1 P 5,3$)^{41}$.

Poznański Synod Archidiecezjalny z lat 1992-1993 zwraca uwage, że współdziałanie kapłanów między sobą realizuje się najbardziej bezpośrednio w ramach dekanatu i odwołuje się do szczegółowych zaleceń Synodu z 1968 r. (Statuty $957-1003)^{42}$. Synod $z$ lat 1992-1993 jednoznacznie podkreśla, że wśród zadań dziekana bardzo ważne sa jego zabiegi mające na celu wytworzenie między kapłanami prawdziwie braterskiej wspólnoty. Dokumenty podkreślają przede wszystkim życzliwość i zaufanie, bez których nie można poprawnie rozumieć współdziałania, zwłaszcza między kapłanami starszymi i młodszymi ${ }^{43}$. Potwierdzają też wagę konferencji dekanalnych, na których omawia się zagadnienia teologiczne, pastoralne, organizacyjne, itp. ${ }^{44}$.

\footnotetext{
${ }^{37}$ Por. SASP, 975.

${ }^{38}$ Tamże, 970.

${ }^{39}$ Por. tamże, 983.

${ }^{40}$ Por. tamże, 9887-989.

${ }^{41}$ Por. tamże, 996.

${ }^{42}$ PSA, tamże, I, 11

${ }^{43}$ Por. tamże.

${ }^{44}$ Por. tamże, II, 19.
} 
Spotkania dekanalne powinny przyczyniać się do pogłębiania wzajemnych relacji kapłanów między sobą. Część ascetyczna i naukowa tych spotkań ma na celu pogłębienie wiedzy i odpowiednią weryfikację stosunku kaplana do zadań wynikających z powolania. Spotkania takie winny być również okazją do wzajemnej wymiany doświadczeń na polu działalności katechetycznej, pracy z grupami istniejącymi w parafiach; miejscem podzielenia się radościami, ale i różnymi trudnościami. Poruszane problemy i sprawy powinny być omawiane $\mathrm{w}$ duchu życzliwości i przyjaźni, a każdy kapłan, zgodnie z pouczeniami Soboru Watykańskiego II, winien szukać wsparcia i rozwiązywania trudności u innego, bardziej doświadczonego kapłana (por. DK 8).

\section{b) Rekolekcje kapłańskie}

Synody Poznańskie wyraźnie zalecają odbywanie przez kapłanów corocznych rekolekcji oraz dni skupienia w celu pogłębienia swej jedności z Bogiem. W dokumentach zwraca się uwagę, że tego rodzaju spotkania przyczyniają się także do głębszego przeżywania wspólnoty kapłańskiej w braterstwie, radości i zaufaniu $^{45}$. Rekolekcje są ważnym elementem formacji kapłańskiej. Postanowienia Poznańskiego Synodu Archidiecezjalnego z lat 1992-1993 zobowiązuja kapłanów do dziesiątego roku po święceniach do corocznego udziału w rekolekcjach zamkniętych w domach rekolekcyjnych na terenie Archidiecezji. Kapłani starsi natomiast mają obowiązek odbyć takie rekolekcje co dwa lata ${ }^{46}$.

Rekolekcje dla kapłanów stają się okazją do osobistego spotkania z Jezusem Chrystusem, Najwyższym Kapłanem. Mają one pomóc kapłanowi coraz ściślej jednoczyć się z Bogiem, zgłębiać swoje kapłańskie powołanie i przyczyniać się do bardziej osobistego angażowania się w pracę duszpasterską. Synody mocno podkreślają, ze rekolekcje to także czas zawiązania serdecznych więzów przyjaźni z innymi kapłanami i umacniania ich w ramach kapłańskiej wspólnoty. Im głębsza będzie jedność kapłanów z Chrystusem, tym owocniejsza będzie również braterska więź między poszczególnymi kapłanami. Te międzyludzkie więzi, aby były prawdziwe, szczere i głębokie, muszą mieć swoje źródło w Bogu. Stąd w aspekcie rekolekcji jako stałego procesu formacji kaplańskiej jawi się również umacnianie więzi sakramentalnych kapłanów między sobą.

\section{c) Wspólnoty kapłańskie}

Kapłani mają również obowiązek uczestniczyć w tak zwanych konferencjach rejonowych organizowanych przez Kurię Metropolitalna, które odbywaja się w różnych ośrodkach na terenie Archidiecezji. Konferencje te tematycznie

\footnotetext{
${ }^{45}$ Por. SASP, 1124.

${ }^{46}$ Por. PSA, II, 19.
} 
obejmują istotne elementy z życia wewnętrznego kapłanów, jak również wprowadzaja $w$ roczny plan duszpasterstwa i ukazuja nowe problemy duszpasterskie $^{47}$. Synod zaleca, aby sami kapłani korzystając $z$ wolnego czasu, spotykali się na wspólnej modlitwie i refleksji duszpasterskiej, a także korzystali z istniejących w diecezji grup.

Poza obowiązkowymi spotkaniami, ważna jest również troska o rozwój wspólnot kapłańskich na płaszczyźnie relacji międzyparafialnych i parafialnych. Statuty Synodu z 1968 r. zachęcają również do podtrzymywania w dekanacie wieczorów organizowanych na wzór wigilijnego, czy na przykład dni wikariuszowskich albo proboszczowskich. Spotkania takie mają służyć zacieśnieniu braterstwa, a także pogłębianiu wiedzy. Praktyką godną pochwały jest organizowanie przez kapłanów kursowych spotkań z okazji rocznicy świeceń kapłańskich. Młodzi księża wykorzystują takie spotkania do umacniania więzi braterskich między sobą. Spotkania takie stają się okazją do udzielania koleżeńskiej pomocy lub, w wypadku potrzeby, dyskretnego upomnienia ${ }^{48}$.

Każdego kapłana, na mocy przyjętych święceń łączą z innymi członkami prezbiterium szczególne więzy apostolskiej miłości, posługi i braterstwa. Braterstwo kapłańskie i przynależność do presbyterium sq elementami charakteryzujqcymi kapłana. W szczególny sposób wyraża to $w$ czasie święceń kapłańskich obrzęd włożenia rqk przez biskupa, w którym biorq udział wszyscy obecni kapłani, by podkreślić zarówno uczestnictwo w tym samym stopniu urzędu, jak również to, że kapłan nie może działać sam, ale zawsze $w$ ramach presbyterium, stajqc się wspótbratem tych wszystkich, którzy je tworzq ${ }^{49}$. Dyrektorium przestrzega przed traktowaniem kapłaństwa w sposób wyizolowany i subiektywistyczny. Kaplan należąc do prezbiterium winien dą̇yć do rozwijania więzi braterskiej, dajac drugiemu kapłanowi i przyjmujac od niego wyrazy przyjaźni, serdecznej pomocy, życzliwości, upomnienia braterskiego, w świadomości, że łaska święceń »ogarnia i wywyższa ludzkie zwiq̨zki między kapłanami, ich więzi psychologiczne, uczuciowe, przyjacielskie i duchowe (...) i przybiera konkretny kształt $w$ najróżnorodniejszych formach wzajemnej pomocy, nie tylko duchowych, ale takze materialnych $(P D V, 74)^{50}$. Dlatego w budowaniu i umacnianiu braterskiej więzi między kapłanami niezmiernie ważną rolę odgrywa współpraca jaka powinna istnieć między prezbiterami w parafiach oraz dekanacie. Wspó1praca ta powinna się przejawiać na różnych płaszczyznach działalności duszpasterskiej. W takim świetle obowiązkowe dla kapłanów spotkania dekanalne i

${ }^{47}$ Por. tamże.

${ }^{48}$ Por tamże, 1054 1994. 25.

${ }^{49}$ Kongregacja ds. Duchowieństwa: Dyrektorium o posłudze i życiu kapłanów. Watykan

${ }^{50}$ Tamże, 74. 
innego rodzaju spotkania moga tylko pomagać kapłanom w pokonywaniu codziennych trudów duszpasterskich, a jednocześnie przyczyniać się do tworzenia się między nimi szczerego braterstwa.

\section{Braterstwo sakramentalne $\mathrm{w}$ relacji proboszcz - wikariusz}

»Tożsamość kapłańska, podobnie jak tożsamość chrześcijańska, ma swe źródło w Trójcy Przenajśw wię tszej«, która się objawia i udziela ludziom w Chrystusie, tworzqc w Nim i za sprawq Ducha Kościól (...). W tajemnicy Kościoła, będqcej tajemnicq komunii trynitarnej (...), ujawnia się specyficzna tożsamość kapłana i jego posługi. Prezbiter na mocy konsekracji otrzymanej w sakramencie święceń, zostaje posłany przez Ojca za pośrednictwem Jezusa Chrystusa, Głowy i Pasterza Ludu Bożego, do którego upodabnia się w sposób szczególny, aby żyć $i$ działać w mocy Ducha Świętego w służbie Kościoła i zbawienia świata (...). Poprzez kapłaństwo, które wyplywa z niepojętej tajemnicy Boga, czyli z miłości Ojca, laski Jezusa Chrystusa i daru jedności Ducha Świętego, kapłan zostaje sakramentalnie wlqczony we wspólnotę z biskupem i z innymi prezbiterami, by służyć Ludowi Bożemu (...). Prezbiter odnajduje pełnq prawdę o swojej tożsamości w tym, że jego kapłaństwo pochodzi od Chrystusa, jest szczególnym uczestnictwem i kontynuacjq samego Chrystusa, Najwyższego i jedynego Kapłana Nowego i Wiecznego Przymierza. Kapłan jest żywym i przejrzystym obrazem Chrystusa kapłana. Oto, co pisze Jan Paweł II w Adhortacji apostolskiej Pastores dabo vobis" z 1992 roku $^{51}$.

Kapłaństwo Jezusa Chrystusa było służbą Ludowi Bożemu, stąd kapłaństwo urzędowe, korzeniami tkwiące w jedynym kapłaństwie Chrystusa, jest kapłaństwem służebnym. W taki właśnie sposób kapłan winien je realizować. Stąd każde działanie kapłana powinno być spełniane w duchu służby, która powinna się ujawniać również na płaszczyźnie współżycia kapłanów między soba.

W swej Adhortacji Papież Jan Paweł II zdecydowanie podkreśla konieczność utrzymywania przez kapłana więzi z innymi ludźmi. Muszą one być oparte na milości ogarniającej całą osobę. Wśród fundamentalnych cech budujących więź międzyosobową Ojciec Święty wymienia: uprzejmość, gościnność, szczerość w słowach i intencjach, roztropność, dyskretność, wielkoduszność, gotowość do służby, zdolność utrzymywania otwartych i braterskich kontaktów z innymi, umiejętność zrozumienia, przebaczenia i pocieszania ${ }^{52}$. Mając na uwadze wymienione przez Papieża Jana Pawła II cechy warunkujące właściwe

\footnotetext{
${ }^{51}$ Jan Paweł II: Pastores dabo vobis, dz. cyt., 12.

52 Por. tamże, 43.
} 
współżycie kapłanów z innymi ludźmi, widzimy, jak kształtują się relacje, jakie powinny istnieć między samymi kaplanami.

Jak już sygnalizowano wcześniej, między proboszczem a wikariuszem, jako najbliższym współpracownikiem $w$ parafii, powinna istnieć prawdziwie braterska więź, wyrażająca się w życzliwym odnoszeniu się do siebie, poważnym traktowaniu i wspóldziałaniu dla dobra Kościoła. Dyrektorium o życiu i posłudze kapłanów jednoznacznie wyraża swoją opinię na temat przyjaźni kapłańskich, widząc w nich źródło pokoju i radości w owocnym pełnieniu posługi. Głęboka i dojrzała przyjaźń wśród kapłanów, staje się także oparciem w trudnościach, jakie ich spotykają w realizowaniu swojej pasterskiej misji. Wspierani wzajemnie szczerą przyjaźnią, kaplani potrafią wyjść naprzeciw tym spośród nich, którzy szczególnie potrzebują zrozumienia, pomocy i wsparcia ${ }^{53}$.

Relacja, jaka zachodzi między proboszczem a wikariuszem, zwykle uwarunkowana znaczną różnicą wieku, winna być oparta na szczerym braterstwie. Dyrektorium w oparciu o Kodeks Prawa Kanonicznego stwierdza: proboszczowie powinni rozwijać życie wspólne $w$ domu parafialnym ze swoimi wikariuszami, pobudzajqc ich do gorliwości jako swoich współpracowników i uczestników troski duszpasterskiej; wikariusze ze swej strony, w celu budowania więzi kapłańskiej, powinni uznać i szanować autorytet proboszcza ${ }^{54}$.

Z powyższych zaleceń wynika obowiązek troski o wytworzenie się i umacnianie więzi braterskich między kapłanami w parafii. Proboszcz, jako doświadczony kapłan, winien przede wszystkim swemu wikariuszowi dawać odpowiedni przykład kapłańskiego życia i stwarzać na probostwie odpowiednią, pełną życzliwości i otwartości atmosferę. Młodemu kapłanowi - wikariuszowi powinien służyć pomocą i radą w konkretnych sytuacjach, jak to zalecały już dokumenty Soboru Watykańskiego II: jako starsi wiekiem, niech przyjmujq młodszych jak braci $i$ wspomagajq $w$ pierwszych poczynaniach i ciężarach posługiwania, niech starajq się zrozumieć ich sposób myślenia, chociaż różny od własnego, i niech z życzliwościq śledzq ich inicjatywę ${ }^{55}$.

Zadanie budowania więzi kapłańskiej spoczywa również na wikariuszu. Jako współpracownik proboszcza powinien również włączyć się w wypełnianie zadań duszpasterskich. Jako „młodszy”, winien szanować wiek i doświadczenie proboszcza, radzić się go w sprawach dotyczących duszpasterstwa i chętnie współdziałać z nim w tych sprawach ${ }^{56}$. Jeżeli w stosunkach między kapłanami a

\footnotetext{
${ }^{53}$ Por. Dyrektorium o posłudze i życiu kaplanów, dz. cyt., 28.

${ }^{54}$ Tamże, 29.

${ }^{55}$ DK 8.

${ }^{56}$ Por. tamże.
} 
wiernymi Sobór zaleca postawę braterstwa na wzór braterstwa jakie istniało między Jezusem a apostolami, to tym bardziej odniesienie takiej relacji winno mieć miejsce w stosunkach proboszcza i wikariusza.

Całość działań kaplanów prowadzi do służby Ludowi Bożemu. Skuteczności realizacji celów duszpasterskich, niezaprzeczalnie sprzyja jedność kapłańska, ich dyspozycyjność, gotowość do pełnienia zadań stosownie do okoliczności i zapotrzebowań. Kompetentne kierownictwo pasterza parafii wymaga umiejętności pracy zespołowej. Działanie wspólnotowe umożliwia znacznie specjalizacje kapłanów, pozwala lepiej wykorzystać ich wzajemne uzupełniajqce się zdolności, niweluje indywidualne braki, zapewnia wzrost efektywności - stwarza warunki do zrealizowania rzeczywistych wspólnot, umożliwia zrozumienie nowych problemów religijnych wiernych (...). Kierownik wspólnoty winien zadbać o rzeczywiste braterstwo swoich współpracowników. Realizuje się ono przez planowane, koordynowane działanie, więź przyjaźni, codzienne szczere i życzliwe kontakty, pomoc, zrozumienie, szacunek dla doświadczenia i wieku, wyzwalanie i popieranie inicjatyw - szczególnie młodych, udzielanie i przyjmowanie rad, cierpliwość, pomoc - szczególnie dla słabych i załamanych. We wzajemnych kontaktach kapłanów starszych i młodszych - motywy teologiczne powinny przeważać nad względami emocjonalnymi. Do zadań kierownika wspólnoty należy też troska o to, aby mimo indywidualizmu i odrębności współpracowników powstała prawdziwa jedność, konieczna do skutecznej odnowy Kościoła ${ }^{57}$.

\section{Permanentna formaça kapłanów gwarantem umocnienia i rozwoju braterstwa sakramentalnego}

Więź braterska, jaka powstaje między poszczególnymi prezbiterami, winna być głęboko osadzona w Chrystusie. Stąd, aby więzi braterskie kapłanów między sobą były rzeczywiście głębokie i szczere, kapłani muszą przede wszystkim starać się umacniać swoją więź z Wiecznym Kapłanem - Jezusem Chrystusem. Jest to możliwe jedynie dzięki stałej formacji, o którą oni sami muszą usilnie się starać, i do której względem nich zobowiązany jest Kościót $1^{58}$. Liczne dokumenty Kościoła podkreślają ogromną rolę formacji duchowej kaplanów dla umocnienia i rozwoju braterstwa sakramentalnego.

Wypowiadając się na temat życia wewnętrznego kapłanów, Synod z 1968 r. zwraca się najpierw $\mathrm{z}$ apelem do kapłanów o ich troskę o stałą nadprzyrodzoną

${ }^{57}$ Z. Jonaczyk: Kapłan - kierownik wspólnoty parafialnej. W: Osobowość kapłańska. Red. J. Majka. Wrocław 1976 s. 211.

${ }^{58}$ Por. J. Ratzinger: O naturze kaplaństwa. „Pastores”. R. 1: 1998 nr 1s. 36-37. 
odnowę wewnętrzną i zabieganie o świętość ${ }^{59}$. Każdy kapłan winien bez przerwy trwać w łasce uświęcającej i starać się o nieustanny rozwój swego uczestnictwa w życiu Boga. Wówczas będzie osiagal doskonałość życia chrześcijańskiego, polegająca na goracej, wytrwałej i czynnej miłości Boga i bliźniego. Kapłana winna cechować niezachwiana wiara. Jego praca duszpasterska ma być konsekwencją życia wiary, stąd każdy kapłan ma czuwać nad cnotą wiary, pogłębiać i umacniać ją oraz świadczyć o Bogu swoim życiem. Ku dojrzałości duchowej kapłana niezbędne jest również posłuszeństwo, rozumiane jako naśladowanie Jezusa w Jego bezgranicznym poddaniu się woli Ojca. W życiu kapłana posłuszeństwo zapewnia jedność i harmonijną współpracę $\mathrm{z}$ biskupem i wiernymi oraz jednoczy z wolą Bożą ${ }^{60}$. Również celibat, do którego zobowiązani sa prezbiterzy, Statuty za Soborem Watykańskim II określając jako znak, a zarazem bodziec miłości pasterskiej i szczególne źródło duchowej płodności $W$ świecie ${ }^{61}$, stanowi środek do podtrzymywania serdecznej i braterskiej wspólnoty kapłańskiej $^{62}$. Ponadto, w celu duchowego rozwoju wewnętrznego, Synod postuluje ubóstwo, czynne miłosierdzie, troskę o prawość sumienia oraz wierne wypełnianie powierzonych obowiązków ${ }^{63}$.

Podejmując problem intelektualnego rozwoju kapłanów, Synod zaleca: systematyczna lekturę Pisma Świętego i komentarzy skrypturystycznych, studium pism Ojców Kościoła, Stolicy Apostolskiej, dokumentów soborowych, dzieł wybitnych i uznanych teologów, konferencje dekanalne, zjazdy duchowieństwa i kursy specjalistyczne, korzystanie z czasopism kapłańskich i ogólnoreligijnych, kontakty ze świeckimi specjalistami ${ }^{64}$.

Poznański Synod Archidiecezjalny z lat 1992-1993, wypowiadając się na temat formacji kapłańskiej, podkreśla konieczność osobistego zaangażowania się kapłanów. Podstawą tego wysiłku jest autentyczna i nadprzyrodzona wiara. Zatem, w centrum nieustannej troski kapłana stoi jego zwiqzek z Chrystusem, Najwyższym Kapłanem oraz staranie o rozwój życia i modlitwy ${ }^{65}$. Dokumenty synodalne podkreślają również, podobnie jak Statuty Synodu z 1968 r., konieczność zachowania celibatu oraz posłuszeństwo biskupowi. Kaplan winien stale odnawiać w sobie dar celibatu i rozwijać jego owce przez wytrwałą modlitwę oraz regularną spowiedź świętą. Ważnym jest podtrzymywanie serdecznych i braterskich więzi ze wspólnotq kapłańskq. Kapłani winni starać się o to, by ich kole-

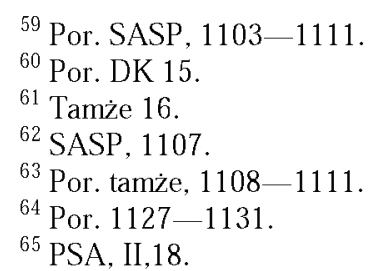


żeńskie i braterskie spotkania przeniknięte byly obecnościq Chrystusa, a w konsekwencji budowały ich, a nie gorszyły ${ }^{66}$.

Według dokumentów tego Synodu formacja obejmuje trzy zasadnicze aspekty życia kaplańskiego: jego stronę duchową, intelektualną i pastoralną, które są ze sobą ściśle powiązane i wzajemnie się uzupełniaja ${ }^{67}$. Zadania pastoralne, które stanowią główne powolanie kapłana, nie są możliwe do zrealizowania bez odpowiedniej wiedzy teologicznej oraz bez osobistego świadectwa życia kapłana, który przepowiadając innym Chrystusa, musi być z Nim ściśle zjednoczony. Ramy organizacyjne formacji duchowej, dotyczące rekolekcji i różnorodnych spotkań kaplańskich, zostały omówione w pierwszej części tego rozdziału. Udział w proponowanych przez Kurię oraz dziekana spotkaniach kapłani winni traktować jako obowiązkowy i starać się czerpać z nich dla siebie jak największe korzyści w celu umacniania swego powolania. Synod, za Soborem Watykańskim II, przypomina też o konieczności pogłębiania wiedzy teologicznej przez kapłanów. Troska kaplanów o intelektualny rozwój jest ściśle związana ze spełnianiem przez nich kapłańskiego powołania. W Archidiecezji Poznańskiej istnieja następujące możliwości i formy zrealizowania postulatu o formacji intelektualnej kaplanów: systematyczne studia specjalistyczne, licencjackie i doktoranckie; czteroletnie Studium Pastoralne dla Kapłanów, do którego zobowiązani są kapłani po drugim roku od święceń kapłańskich; coroczne dwudniowe kursy dla kapłanów, które obejmują zagadnienia teologiczne i duszpasterskie; konferencje rejonowe i dekanalne ${ }^{68}$.

W każdym dekanacie wybierany jest jeden kapłan, który spełnia rolę moderatora. Ma on być promotorem doskonałości kapłańskiej w dekanacie ${ }^{69}$. Moderator dekanalny ma czuwać nad pielęgnowaniem życia wewnętrznego i rozwojem świętości kapłanów w dekanacie; ma podtrzymywać i rozwijać nadprzyrodzoną miłość i jedność między kapłanami oraz między kaplanami a biskupem. Moderator $\mathrm{w}$ uzgodnieniu $\mathrm{z}$ dziekanem musi organizować godziny skupienia podczas konferencji dekanalnych i dekanalne dni skupienia, na których wygłasza konferencje ascetyczne, służy okazją do spowiedzi świętej, utrzymuje stały duchowy kontakt $z$ kapłanami na wzór kierownika duchowego ${ }^{70}$. Aby formacja była pełna, musi być systematyczna czyli stała. Ważne jest przyzwyczajenie kaplana do osobistego studium. Formacja powinna więc również posiadać charakter osobisty. Każdy prezbiter winien czuć się zachęcony słowem i przykładem swego

\footnotetext{
66 Tamże.

${ }^{67}$ Por. tamże, II, 19.

${ }^{68}$ Por. tamże.

${ }^{69}$ SASP, 965.

${ }^{70}$ Por. tamże, 966 - 969.
} 
biskupa oraz współbraci w kapłaństwie do podjęcia współodpowiedzialności za formację ${ }^{71}$.

Dla realizacji formacji kapłańskiej pożyteczne są różne spotkania kapłańskie. Program takich spotkań winien być jednorodny, aby kaplan coraz bardziej mógł upodabniać się do Chrystusa oraz winien charakteryzować się stopniowym rozwojem. Spotkania kapłańskie są konieczne, aby: wzrastać we wzajemnej komunii, coraz głębiej uświadamiać sobie problemy, z którymi kapłani spotykają się w swojej pracy i umiejętnie do nich podchodzić ${ }^{72}$.

Dla młodych kapłanów, zwłaszcza neoprezbiterów, bardzo ważna jest praktyka formacji stałej. Przejście od formacji seminaryjnej do sprawowania świętej posługi, winno być dokonane z pomocą wybranych, doświadczonych kapłanów; dlatego postuluje się o tak zwany rok duszpasterski dla neoprezbiterów. W ciagu takiego roku należy czuwać, by nowo wyś wię ceni nie byli stawiani w szczególnie trudnych lub delikatnych sytuacjach, oraz należy unikać wyznaczania im takich zadań, których podjęcie oddalałoby ich od wspótbraci. Byłoby natomiast wskazane, popieranie jakiejśs właściwej formy życia wspólnego ${ }^{73}$. Biskup winien kierować nowo wyświęconego kaplana do współbraci dających przykład życia i gorliwości duszpasterskiej, aby ci we właściwy sposób ukierunkowali młodych prezbiterów. Ten rok winien zaowocować także umocnieniem więzi między prezbiterem a biskupem, analogicznej do więzi syna z ojcem ${ }^{74}$.

Odpowiednim środkiem i adekwatnym do stałej formacji duchowieństwa sa organizowane dni skupienia i rekolekcje. Są one dla kapłanów czasem, w którym winien on na nowo odnaleźć Boga i siebie samego, zagłębiając się w medytacji i modlitwie. Podczas takich spotkań ważne jest skoncentrowanie się na tematach duchowych, poświęcenie obszernego czasu milczeniu i modlitwie, szczególna troska o sprawowanie liturgii, sakrament pokuty, adoracja eucharystyczna, kierownictwo duchowe i akty czci i kultu Najświętszej Maryi Panny ${ }^{75}$. Za formację duchową w pierwszym rzędzie odpowiedzialny jest sam kapłan, uczestniczq̨ $W$ jedynym kapłaństwie Chrystusa, jest on powołany do ukazywania $i$ wypełniania swego jedynego i niepowtarzalnego powołania ${ }^{76}$.

\footnotetext{
${ }^{71}$ Por. Dyrektorium o posłudze i życiu kaplanów, dz. cyt., 79 i 80 oraz Adhortacja apostolska Pastores dabo vobis, dz. cyt., 79

${ }^{72}$ Por. Dyrektorium o posłudze i życiu kapłanów, dz. cyt., 81 .

73 Tamże, 82 .

${ }^{74}$ Yor. tamże.

${ }^{75}$ Por. tamże, 85

76 Tamże, 87
} 
We wszystkich aspektach życia kapłańskiego wyłaniają się szczególne więzy miłości apostolskiej, posługi i braterstwa, na których opiera się wzajemna pomoc, jakq winni okazywać sobie prezbiterzy. Należy życzyć sobie, aby wzrastała i rozwijała się współpraca wszystkich kapłanów w trosce o ich życie duchowe i ludzkie, jak również posługe kaplańskq ${ }^{77}$.

Literatura źródeł i literatura przedmiotu pozwoliła nam dojść do pewnych wniosków. Braterstwo sakramentalne jako szczególna więź lącząca kapłanów od chwili przyjęcia święceń, stanowi ważny element życia kapłana. Podstawą braterstwa kapłanów między sobą jest ich lączność z Chrystusem Najwyższym i Wiecznym Kapłanem. Chrystus jest zawsze inicjatorem powołania kapłana. Powołany, wybrany jest przez Boga dla Niego samego, dlatego winien swą misję pojmować jako służbę Bogu oraz Ludowi Bożemu, do którego jest posłany dla realizacji Królestwa Bożego. Kapłan, z woli Chrystusa, dla dobra Kościoła, nigdy nie działa sam, lecz w jedności z Chrystusem Głową i Pasterzem oraz w łączności z innymi kapłanami. Tak jak kiedyś Apostołowie ustanowieni przez samego Chrystusa tworzyli grono, czyli kolegium, działali we wspólnocie, „po dwóch" nauczali i wypełniali Bożą misję, tak i obecnie każdy kapłan należy do presbyterium, czyli do wspólnoty kapłanów zjednoczonych wokół swego biskupa. W ten sposób powstaje specjalna więź lącząca kapłanów między sobą, a wyrażająca się w najgłębiej pojmowanym braterstwie. Braterskie relacje powstaja na różnych płaszczyznach tej komunii. Istnieją one między biskupem a prezbiterami oraz między prezbiterami wzajemnie. Ten drugi rodzaj relacji wygląda oczywiście różnie, często zależnie od pełnionych przez kapłanów funkcji - dziekana, proboszcza, czy wikariusza.

Relacja braterska, jaka winna istnieć między proboszczem a wikariuszem, jest relacją szczególna, wynikająca z charakteru pełnionych przez obie strony funkcji. Proboszcz, jako pasterz parafii i dany mu do pomocy duszpasterskiej wikariusz na płaszczyźnie pełnionych zadań muszą stać się współpracownikami ze względu na dobro powierzonych im parafian. Oczywiście wikariusz musi w pełni podporządkować się proboszczowi jako swemu przełożonemu. Mimo jednak relacji przełożony - podwładny, prezbiterów powinna łączyć więź braterskiej miłości, przyjaźni i życzliwości oraz wola jak najlepszej współpracy między soba.

\footnotetext{
77 Tamże, 88 .
} 
